Original scientific article/Izvirni znanstveni članek

\title{
Factors associated with greater potential for alcohol misuse among the students of the Gorenjska region
}

\author{
Dejavniki tveganja za uživanje alkoholnih pijač pri študentih v gorenjski regiji
}

\author{
Sanela Pivač, Brigita Skela-Savič
}

\section{Key words: drinking frequency; students; alcohol \\ Ključne besede: pogostost pitja; študenti; alcohol \\ Lecturer Sanela Pivač, MSc (Nursing), RN \\ Correspondence e-mail/ Kontaktni e-naslov: spivac@fzj.si}

Associate Professor Brigita Skela-Savič, PhD, MSc, RN

Both/Obe: Faculty of Health Care Jesenice, Spodnji Plavž 3 , 4270 Jesenice, Slovenia

The article is based on the Master thesis of Sanela Pivač Attitudes of students attending junior colleges and higher education institutions in the Gorenjska region towards alcohol consumption and abuse (2013)./ Članek je nastal na osnovi magistrskega dela Sanele Pivač Odnos študentov do alkohola in alkoholne problematike na višje- in visokošolskih zavodih v gorenjski regiji (2013).

Prejeto/Received: 22. 7. 2016

Sprejeto/Accepted: 7. 11. 2016

\begin{abstract}
Introduction: Excessive alcohol consumption can stem from different biological, social, environmental, or psychological factors (e.g. peer influence, desire to be accepted within a social group, family history with alcohol addiction, availability of alcohol beverages, poor academic performance, low self-image, etc.). The aim of study was to determine the risk factors associated with alcohol consumption among the undergraduate students in the Gorenjska region.

Methods: A quantitative non-experimental method of research was employed. The data were collected through a structured questionnaire. The purposive sample consisted of 328 first-year undergraduate students in the Gorenjska region. The research was conducted in May, October and November 2012. The data obtained were analysed using the descriptive statistics and multiple linear regression analysis.

Results: The greatest influence on drinking frequency for better sociability and relaxation has the average educational attainment in the last year of secondary education $(\beta=0.168, p=0.002)$. The following factors were identified to have a statistically significant impact on the frequency of alcohol consumption during leisure time: friendship $(\beta=0.131, p=0.029)$, frequent socializing with friends $(\beta=0.127, p=0.035)$, support of the family when in distress $(\beta=-0.183, p=0.001)$ and the average academic achievement in the last year of secondary education $(\beta=0.098, p=0.043)$.

Discussion and conclusion: The risk factors associated with alcohol consumption among the students in the Gorenjska region are mainly social (lack of family support, peer pressure) and personal (low self-image, poor academic achievement and leisure time). Characteristics of the study participants in relation to alcohol consumption do not differ from the rest of the younger population.
\end{abstract}

\section{IZVLEČEK}

Uvod: Pogosti dejavniki tveganja za pitje alkoholnih pijač so želja po sprejetosti s strani vrstnikov, prisotnost alkohola v družini, dostopnost alkohola, slabši študijski uspeh in nižja samopodoba študenta. Namen raziskave je bil ugotoviti dejavnike tveganja, ki so povezani z uživanjem alkoholnih pijač študentov na višjein visokošolskih zavodih $\mathrm{v}$ gorenjski regiji.

Metode: Uporabljena je bila kvantitativna neeksperimentalna metoda raziskovanja. Podatki so bili zbrani s pomočjo strukturiranega vprašalnika na namenskem vzorcu 328 študentov prvih letnikov višje- in visokošolskih zavodov na področju gorenjske regije, v obdobju maj ter oktober in november 2012. Uporabljena je bila opisna statistika in linearna multipla regresijska analiza.

Rezultati: Največji vpliv na pogostost pitja zaradi komunikativnosti in sproščenosti ima povprečni učni uspeh $\mathrm{v}$ zadnjem letu srednješolskega izobraževanja $(\beta=0,168, p=0,002)$. Statistično pomemben vpliv pogostosti pitja alkoholnih pijač $\mathrm{v}$ prostem času predstavljajo prijateljstvo $(\beta=0,131, p=0,029)$, pogosto druženje $\mathrm{s}$ prijatelji $(\beta=0,127, p=0,035)$, opora družine v primeru težav $(\beta=-0,183, p=0,001)$ in povprečni učni uspeh v zadnjem letu srednješolskega izobraževanja $(\beta=0,098, p=0,043)$.

Diskusija in zaključek: Dejavniki tveganja, ki so povezani z uživanjem alkoholnih pijač študentov gorenjske regije so socialni (opora družine), vrstniški (vpliv vrstnikov) in individualni (nizka samopodoba, slabši učni uspeh in preživljanje prostega časa). Značilnosti anketiranih študentov gorenjske regije v odnosu do uživanja alkoholnih pijač ne odstopajo od ostalih vrstnikov. 


\section{Introduction}

Alcohol is the oldest and most widely consumed of all legal recreational drugs during study years (Baker \& Boland, 2011). According to the Ministry of Health (2008), alcohol consumption is the world's sixth largest risk factor for untimely morbidity and mortality worldwide, while in Europe it ranks the third, or the first among youth. Alcohol consumption of the young is a major public health concern (Rassool, 2007). Alcohol is the most commonly misused substance associated with different types of diseases and conditions. The trend of alcohol use among the young, and especially episodes of heavy drinking (binging), is still increasing (Hovnik Keršmanc, 2010). The problem of heavy episodic drinking is common also in other countries. The research conducted among the American students shows that binging may result in poorer academic achievement and lower self-image (Kazemi, et al., 2011).

According to the European School Survey Project on Alcohol and Other Drugs (ESPAD) 2011 (Hibell, et al., 2011), $93 \%$ of the respondents reported using alcohol. Boys drink more frequently and in larger quantities than girls (Stergar, 2011). These results are in line with the findings of the study conducted among the first and the fourth-year students of the University of Maribor (Kolšek \& Klemenc Ketiš, 2015). Alcohol drinking is a perennial problem in the Gorenjska region, widespread among younger as well as older generation. It is disturbing to note that the youngsters attribute to alcohol more positive than negative effects. The greatest positive effect cited was satisfaction and pleasure (Hovnik Keršmanc, 2011).

There are several factors which induce the youngsters to consume alcoholic beverages. These factors include their desire to be accepted by their social group, the environment, alcohol availability, exposure to alcohol advertisements, and a lot of leisure time. The consequences of problematic drinking perpetrated by college age students are varied, serious, damaging, and far reaching, including the adverse effects on their well-being, also a 'hangover', their educational performance, bodily injuries and involvement in fatal car accidents (Snyder, 2006). Several studies indicate that the increasingly stressful environment has led to the increased misuse of alcohol, tobacco and other illegal drugs among the young in the past decades (Varela \& Picakrd, 2011). The peers as well as the adults may have an impact on the risk-taking behaviour of the youngsters (Etcheverry \& Agnew, 2008; Kenna \& Lewis, 2008). Peers act as an influential model and therefore the students are more likely to consume alcohol when accompanied by drinkers than non-drinkers (Cicognani \& Zani, 2011). Seeing one's peers drinking alcohol induces the students to start drinking, which consequently leads to the increased consumption of alcohol (Champion, et al., 2015). The most common risk factor for alcohol drinking and binging are poor family income, ineffective parenting, general social context, poor educational performance, association with deviant peers, early engagement in risk behaviours and drug misuse as well as physiological and genetic factors (Maggs \& Schulenberg, 2006). It was established that higher levels of binge drinking of younger adults are associated with early onset of drinking and higher levels of anxiety and depression (McNamara, et al., 2010).

\section{Aims and objectives}

The purpose of the study was to explore the prevalence of alcohol abuse among the undergraduate students in the Gorenjska region. The study aimed to establish the drinking patterns of the students and to identify the major risk factors associated with the excessive indulgence in drinking alcoholic beverages.

The following hypothesis was formulated and tested:

H1: Student alcohol consumption is related to the following risk factors: stress, lack of social support, social interaction and group acceptance, and the academic achievement in secondary education.

\section{Methods}

The study is based on a quantitative non-experimental research method. The data were collected by using a survey with a structured questionnaire as a research instrument.

\section{Description of the research instrument}

The structured questionnaire was composed of seven sections including different number and types of questions: multiple-choice questions, control list and a 5 -point Likert scale with fixed choice response formats to measure the attitudes or opinions statements. Each of the five responses was attributed a numerical value used to measure the attitude under investigation (1-Strongly Disagree, 2-Disagree, 3-Undecided, 4-Agree, 5-Strongly Agree). The questionnaire design was based on the literature review of the sources related to alcohol consumption (Watson, et al., 2006; Zalta, et al., 2008; Tremblay, et al., 2010). The reliability of the questionnaire was tested with the analysis of internal consistency.

The testing of the questionnaire reliability used on the given research sample yielded the following results:

- Cronbach's alpha for 10 statements referring to personal characteristics and social relationships was 0.82 ;

- Cronbach's alpha for 8 statements referring to the adverse effects of alcohol drinking was 0.81 .

The validity of the research instrument was 
explained by the factor analysis of variables. Adequate explanation of variance was achieved. The factors obtained were used in further statistical analysis, as presented in the Results section. Principal components analysis was used to identify a smaller number of uncorrelated variables (the principal components) from a large set of data. A better structure of factor loading was obtained by factor rotation. The principal components analysis yielded three components which could explain $71.6 \%$ of total variance $(\mathrm{KMO}=$ 0.932 and Barlett $p<0.001$ ). The factor 'frequency of drinking alcohol for better sociability and relaxation', which includes three statements, explains $47.66 \%$ of variance; the factor 'frequency of drinking during leisure time', which includes three statements, explains $13.41 \%$ of variance; the factor 'drinking alcohol to alleviate stress and problems', which includes four statements, explains $10.60 \%$ of variance. In further statistical analysis all three factors were considered.

\section{Description of the research sample}

The research sample consisted of undergraduate students in Gorenjska region. In this region, there are 3 colleges and 7 higher professional education institutions. The list does not include the institutions (3) where only part-time studies are available. The sample was reduced to the students of two colleges and two higher professional education institutions as the remaining ones did not give their consent to be included in the study or missed the deadline for participation. The purposive sample consisted of the following institutions: Intercompany education and training centre Kranj, Vocational college; Škofja

Table 1: The number of the first-year students enrolled in the academic years 2011/12 and 2012/13 and the number of students from higher education institutions in the Gorenjska region who participated in the study Tabela 1: Stevilo študentov, vpisanih $v$ prvi letnik $v$ študijskem letu 2011/12 oz. 2012/13, in število $v$ raziskavo vključenih študentov po gorenjskih višje- in visokošolskih zavodih

\begin{tabular}{|c|c|c|c|}
\hline $\begin{array}{l}\text { Higher education institution } \\
\text { (academic year of enrolment) }\end{array}$ & $n_{1}$ & $n_{2}$ & $\%$ \\
\hline $\begin{array}{l}\text { Intercompany education and training } \\
\text { centre Kranj, } \\
\text { Vocational college }(2012 / 13)\end{array}$ & 91 & 35 & 38.5 \\
\hline Škofja Loka School Centre (2012/13) & 89 & 67 & 75.3 \\
\hline $\begin{array}{l}\text { Faculty of Health Care Jesenice } \\
(2011 / 12 ; 2012 / 13)\end{array}$ & 190 & 131 & 68.9 \\
\hline $\begin{array}{l}\text { Faculty of Organisational Sciences } \\
\text { Kranj (2012/13) }\end{array}$ & 297 & 95 & 32 \\
\hline Total & 667 & 328 & 49.2 \\
\hline
\end{tabular}

Loka School Centre; Faculty of Health Care Jesenice; Faculty of Organisational Sciences Kranj. The research conducted at the Faculty of Health Care Jesenice included two generations of full-time firstyear students enrolled in the academic years 2011/12 and 2012/13, while in other institutions only the fulltime first-year students enrolled in the academic year $2012 / 13$ participated in the study. The sample included the total of 328 students, which represents $49.2 \%$ realisation of the sample (Table 1).

The participants' age ranged from 18 to 20 years (64.6\%), only $4.3 \%$ of the students were aged over 24 years. The sample consisted of $147(44.8 \%)$ males and $181(55.2 \%)$ females. The academic attainment of the majority of the participants in the last year of their secondary education was satisfactory, and only $3.4 \%$ of the participants completed their education with excellent grades.

\section{Description of the research procedure and data analysis}

The study was conducted in May, October and November, 2012. All higher education institutions were invited to provide their informed consent before taking part in the study. The potential research participants were prospectively informed of the purpose and time of the research. After the consent for participation was obtained, the survey was conducted according to the protocol agreed upon by the coordinators of the research in individual institutions. The participants were asked to complete the survey according to instructions. The participation was voluntary, anonymity and confidentiality of the participants was ensured. The data collected were processed by using the SPPS computer programme version 20.0 (SPSS, Chicago, IL, USA), the descriptive statistics and multiple linear regression analysis. The variables were defined on the basis of factor analysis. Linear multiple regression analysis was used to interpret the students' attitudes towards alcohol drinking. The differences with p-value of $5 \%$ or lower were considered to be statistically significant.

\section{Results}

Table 2 shows that the majority of respondents (61.3 $\%)$ consumed their first alcoholic drink at the age of 15 to 18 years, and most of the remaining respondents (36 $\%)$ at the age of 10 to 14 years. Most of the respondents (34.5\%) consume up to 3-4 drinks per occasion and $18.3 \%$ of the respondents consume seven or more drinks per occasion. The majority of the respondents (28.4\%) drink alcohol only on special occasions, i.e. a few times per year and $4.9 \%$ of the respondents drink 3-6 times per week.

The aim of the study was to determine whether the students' alcohol drinking is related to the factors, 
Table 2: Characteristics of the students in relation to alcohol consumption

Tabela 2: Značilnosti anketiranih študentov $v$ zvezi z alkoholom

\begin{tabular}{|c|c|c|}
\hline Statements/Trditve & $n$ & $\%$ \\
\hline \multicolumn{3}{|l|}{ Favourite drinks } \\
\hline Spirits & 101 & 30.8 \\
\hline Beer & 90 & 27.4 \\
\hline Wine & 81 & 24.7 \\
\hline $\begin{array}{l}\text { Alkopop - bottled flavoured alcoholic beverages with relatively low alcohol } \\
\text { content (cca. } 5 \% \text { alcohol by volume) }\end{array}$ & 53 & 17.1 \\
\hline Total & 325 & 100 \\
\hline \multicolumn{3}{|l|}{ Age at first alcohol drinking } \\
\hline Never & 1 & 0.3 \\
\hline Between 10 to 14 years of age & 118 & 36.0 \\
\hline Between 15 to 18 years of age & 201 & 61.3 \\
\hline Between 19 to 22 years of age & 8 & 2.4 \\
\hline Total & 328 & 100 \\
\hline \multicolumn{3}{|l|}{ The average quantity of alcohol consumed per occasion } \\
\hline I do not drink alcohol & 14 & 4.3 \\
\hline $1-2$ drinks & 84 & 25.6 \\
\hline 3-4 drinks & 113 & 34.5 \\
\hline $5-6$ drinks & 55 & 17.3 \\
\hline 7 drinks and more & 60 & 18.3 \\
\hline Total & 326 & 100 \\
\hline \multicolumn{3}{|l|}{ Frequency of drinking alcohol in the previous year } \\
\hline Never & 11 & 3.4 \\
\hline A few times per year, on special occasions & 93 & 28.4 \\
\hline 1 time per month & 59 & 18.0 \\
\hline $2-3$ times per month & 82 & 25.0 \\
\hline $1-2$ times per week & 64 & 19.5 \\
\hline 3-6 times per week & 16 & 4.9 \\
\hline Every day & 3 & 0.9 \\
\hline Total & 328 & 100 \\
\hline
\end{tabular}

Legend/Legenda: $n$ - number/število; \% - percentage/odstotek

Table 3: Results of regression analysis of frequency of alcohol consumption for better sociability and relaxation Tabela 3: Rezultati regresijske analize pogostosti pitja zaradi komunikativnosti in sproščenosti

\begin{tabular}{|c|c|c|c|c|c|}
\hline $\begin{array}{l}\text { Frequency of drinking } \\
\text { for better sociability and } \\
\text { relaxation/ } \\
\text { Pogostost pitja zaradi } \\
\text { komunikativnosti in } \\
\text { sproščenosti }\end{array}$ & $\begin{array}{l}\text { Characteristics/ } \\
\text { Značilnosti }\end{array}$ & $b$ & $\beta$ & $t$ & $p$ \\
\hline \multirow{6}{*}{$\begin{array}{l}\mathrm{R}=0.308 \\
\mathrm{R}^{2}=0.095 \\
\text { pril. } \mathrm{R}^{2}=0.081\end{array}$} & Constant & 0.213 & I & 0.530 & 0.596 \\
\hline & I have a positive self-image. & -0.141 & -0.126 & -2.330 & 0.020 \\
\hline & $\begin{array}{l}\text { What were your average point grades in the } \\
\text { last year of secondary education? }\end{array}$ & 0.238 & 0.168 & 3.130 & 0.002 \\
\hline & $\begin{array}{l}\text { How often do you exercise (at least } 30 \\
\text { minutes a day)? }\end{array}$ & -0.071 & -0.093 & -2.013 & 0.045 \\
\hline & $\begin{array}{l}\text { How often do you watch TV in your leisure } \\
\text { time? }\end{array}$ & 0.140 & 0.118 & 2.202 & 0.028 \\
\hline & $\begin{array}{l}\text { How often do you meet and socialize with } \\
\text { friends in your leisure time (have a cup of } \\
\text { coffee, go to a party)? }\end{array}$ & -0.196 & -0.139 & -2.572 & 0.011 \\
\hline
\end{tabular}

such as lack of family support, low self-image, greater peer acceptance, and poor academic attainment in the secondary education. Results of the study revealed the following average values of the students' family support $(\bar{X}=4.3, s=0.8)$, and self-image $(\bar{X}=3.8, s=$ $0.8)$, using a 5-point Likert's scale.

Regression analysis was used to investigate the relationships between interrelated variables. Three 
Table 4: Results of regression analysis of frequency of alcohol consumption in the respondents' leisure time Tabela 4: Rezultati regresijske analize pogostosti pitja $v$ prostem času

\begin{tabular}{|c|c|c|c|c|c|}
\hline $\begin{array}{l}\text { Frequency of drinking in the } \\
\text { respondents' leisure time/ } \\
\text { Pogostost pitja v prostem } \\
\text { času }\end{array}$ & $\begin{array}{l}\text { Characteristics/ } \\
\text { Značilnosti }\end{array}$ & $\boldsymbol{b}$ & $\beta$ & $t$ & $p$ \\
\hline \multirow{9}{*}{$\begin{array}{l}\mathrm{R}=0.463 \\
\mathrm{R}^{2}=0.214 \\
\text { pril. } \mathrm{R}^{2}=0.194\end{array}$} & Constant & -0.384 & 1 & -0.799 & 0.425 \\
\hline & I have a positive self-image. & 0.104 & 0.093 & 1.676 & 0.045 \\
\hline & I have many friends. & 0.146 & 0.131 & 2.198 & 0.029 \\
\hline & I often socialise with my friends. & 0.148 & 0.127 & 2.123 & 0.035 \\
\hline & $\begin{array}{l}\text { My family supports me when I am in } \\
\text { distress. }\end{array}$ & -0.207 & -0.183 & -3.456 & 0.001 \\
\hline & $\begin{array}{l}\text { When in trouble I seek help from my } \\
\text { teachers. }\end{array}$ & -0.201 & -0.195 & -3.873 & 0.000 \\
\hline & $\begin{array}{l}\text { Average grades in the last year of secondary } \\
\text { education }\end{array}$ & 0.138 & 0.098 & 1.944 & 0.043 \\
\hline & $\begin{array}{l}\text { How often do you spend your leisure time } \\
\text { in nature? }\end{array}$ & 0.117 & 0.098 & 1.933 & 0.044 \\
\hline & $\begin{array}{l}\text { How often do you spend your leisure time } \\
\text { with your friends? (have a cup of coffee or } \\
\text { go to a party)? }\end{array}$ & -0.315 & -0.224 & -4.160 & 0.000 \\
\hline
\end{tabular}

Legend/Legenda: $b$ - regression coefficient/regresijski koeficient, $\beta$ - standardized regression coefficient/standardizirani regresijski koeficient; $R$ - correlation coefficient/korelacijski koeficient; $R^{2}$ - the average of all total achievements/povprečje vseh skupnih dosežkov; pril. $R^{2}$-explanatory proportion of variability/delež pojasnjevalne variabilnosti; $t$ - coefficient value/vrednost koeficienta; p-statistical significance/statistična značilnost

regression models were developed with dependent and independent variables obtained by factor analysis: frequency of alcohol consumption for better sociability and relaxation, drinking in the respondents' leisure time, and drinking because of stress and other problems. The following average values of the factors were obtained: $3.5(s=1.1)$ for 'frequency of alcohol consumption for better sociability and relaxation', 3.2 $(s=0.9)$ for 'drinking in the respondents' leisure time, and $2.2(s=0.8)$ for 'drinking because of stress and other problems'.
As shown in Table 3, the following factors have a statistically significant impact on drinking frequency for better sociability and communication: positive selfimage $(\beta=-0.126, p=0.020)$, average point grades in the last year of secondary education $(\beta=0.168$, $p=0.002$ ), frequency of physical exercises (at least 30 min. per day) $(\beta=-0.093, p=0.045)$, watching TV in leisure time $(\beta=0.118, p=0.028)$ and socialising with friends in leisure time $(\beta=-0.139, p=0.011)$. These factors explain $8.1 \%$ of the total variability of the frequency of drinking because of better sociability and

Table 5: Results of regression analysis of the consequences of drinking due to stress and other problems Tabela 5: Rezultati regresijske analize pitja kot posledice blaženja stresa in težav

\begin{tabular}{|c|c|c|c|c|c|}
\hline $\begin{array}{l}\text { Drinking as a result of stress } \\
\text { and problems/Pitje kot } \\
\text { posledica blaženja stresa in } \\
\text { težav }\end{array}$ & Characteristics/Značilnosti & $\boldsymbol{b}$ & $\beta$ & $t$ & $p$ \\
\hline \multirow{6}{*}{$\begin{array}{l}\mathrm{R}=0.373 \\
\mathrm{R}^{2}=0.139 \\
\text { pril. } \mathrm{R}^{2}=0.120\end{array}$} & Constant & -0.255 & I & -0.484 & 0.629 \\
\hline & I often socialise with my friends. & 0.131 & 0.113 & 1.958 & 0.051 \\
\hline & $\begin{array}{l}\text { My family supports me when I am in } \\
\text { distress. }\end{array}$ & -0.186 & -0.165 & -3.032 & 0.003 \\
\hline & $\begin{array}{l}\text { Average grades in the last year of secondary } \\
\text { education }\end{array}$ & 0.263 & 0.186 & 3.520 & 0.000 \\
\hline & How often do you visit shopping centres? & -0.172 & -0.115 & -2.138 & 0.033 \\
\hline & $\begin{array}{l}\text { How often do you spend your leisure time } \\
\text { with your friends? (have a cup of coffee or } \\
\text { go to a party)? }\end{array}$ & -0.184 & -0.131 & -2.295 & 0.022 \\
\hline
\end{tabular}


communication. The average point grades in the last year of secondary education was the factor influencing drinking frequency to the largest extent $(\beta=0.168)$.

The regression analysis shows a statistically significant impact of individual variables studied on the frequency of alcohol drinking in one's leisure time (Table 4$)$. The variables referred to the positive selfimage $(\beta=0.093, p=0.045)$, friendship $(\beta=0.131$, $p=0.029$ ), frequency of meeting friends and socialising $(\beta=0.127, p=0.035)$, family support when in distress $(\beta=-0.183, p=0.001)$, teachers' support when in distress $(\beta=-0.195, p=0.000)$, average grades in the last year of secondary education $(\beta=0.098, p=$ $0.043)$, spending leisure time in nature $(\beta=0.098$, $p=0.044)$ and spending leisure time with friends $(\beta=$ $-0.224, p=0.000)$. These factors explain $19.4 \%$ of the total variability of the frequency of drinking during holidays and weekends.

As shown in Table 5, the frequency of drinking due to the stress and other problems is associated with family support $(\beta=-0.165, p=0.003)$, average grades in the last year of secondary education $(\beta=0.186, p=$ $0.000)$, spending leisure time in large shopping centres $(\beta=-0.115, p=0.033)$, socialising with friends $(\beta=$ $-0.131, p=0.022)$. These factors explain $12 \%$ of the total variability of the frequency of drinking as a mode of alleviating stress and coping with problems during examination period and weekdays.

\section{Discussion}

The purpose of the study was to explore the relationships between the students' attitudes, their sociodemographic characteristics and risk factors in relation to alcohol consumption. The study results indicate that alcohol use and misuse is fairly common among the studied population. Only $4.3 \%$ of the respondents never drink alcohol. Generally, alcohol consumption is high, which can result in various alcohol-related conditions.

The age of onset for alcohol drinking in a large proportion of the respondents was 10-14 years, in which respect they do not differ from the rest of the population. The average age of alcohol initiation in Slovenia is 13 years (Inštitut za varovanje zdravja, 2010). Other studies have also established a high percentage of heavy and risky drinking among the students of the University of Ljubljana (Biščak, et al., 2014).

The most popular alcoholic drinks among the respondents are spirits and beer. According to the 2011 ESPAD Report, beer is the dominant beverage among boys in a large majority of the countries studied. Spirits is the most important beverage among girls in just over half of the countries. On average, these two beverages account for about $70 \%$ of the students' total consumption (Hibell, et al., 2011). The increased average quantity and frequency of drinking has been reported in all European countries, and in Slovenia, an increase in binge drinking, or heavy episodic drinking, has been noted. The results of various studies show that the reasons to indulge in drinking include: having fun, feeling relaxed, feeling more friendly and outgoing, greater self-esteem and better self-image, feeling happy, acceptance by older peers, identification with one's role models (Jeriček Klanšček, et al., 2007).

It is apparent from this study that the factors associated with consumption of larger quantities of alcohol include drinking for better sociability and relaxation, poor average grades, negative self-image and more frequent socialising with friends. The students in Great Britain report that they drink alcohol to feel good and for relaxation purposes (Watson, et al., 2006). It is typical of today's youth to relax and have fun under the influence of alcohol. They may be shy, uncomfortable and withdrawn, but under the influence of alcohol they open up, relax and like to brag about their achievements. Getting drunk in a company makes young people do things they would never do when sober (Ramovš \& Ramovš, 2007). According to Hibel and collegues (2011), the students drink alcohol in order to have fun and forget their problems.

The findings of the present research indicate that the students who suffer from negative self-image tend to use alcohol more frequently. A young person's self- image is affected by many factors, such as parental influence, friends, the media etc. Self-image is an important factor, determining the quality of life, social relations and individual's abilities. It was also established that poor academic achievement, lack of family support and frequent socialising with friends may have a significant impact on alcohol consumption. There are, however, other risk factors which were not considered in the study. Alcoholic beverages are easily available, socially acceptable and often available in home environment (Anderson \& Baumberg, 2006). Slovenia is culturally similar to other wine countries where the production and consumption of home-produced alcoholic beverages is common. It is therefore not surprising that many young people have their first drink at home (Bajt \& Zorko, 2006). Prohibition is only one of the measures used to restrict the availability of alcohol. Along with prohibition, there are other prevention strategies. Young people should be encouraged to follow the alcohol prevention programmes and be informed about the consequences of alcohol drinking by raising their awareness of its possible detrimental effects through social networks and health promotion workshops. Numerous educational programmes have been developed by student and non-governmental organisations which are dedicated to the prevention of harmful alcohol use and alcohol dependence among the younger population. The two most known and successful programmes in Slovenia are 'Sporočilo v steklenici' 'A message in the bottle' and 'Z glavo na zabavo' 'Use your head when going to a party'. Makivić and collegues (2013) maintain that the enforcement of 
restricted access would be an effective policy to avoid alcohol-related diseases and deaths. Slovenia has already adopted some effective measures to reduce the frequency and quantity of alcohol consumption, including higher taxation of alcoholic beverages, limited access to public drinking places and the control of alcohol use in student campuses.

The current study also identified a negative correlation between alcohol drinking and lack of family support when coping with stress and anxiety. The students drink more if they are not supported by their family, which has the central and enduring influence on children's overall growth and development. An unambiguous positive relationship has been established between favourable family environment, including high levels of parental awareness and communication, and a lowered probability of risky alcohol use. According to Osler and collegues (2006), and Choo and Shek (2013), the quality of child-parent relationship, the level of family conflict, parents' drinking patterns and family structure have a strong impact on the frequency of adolescents' drinking and drunkenness. Adolescents experiencing high family conflict more frequently indulge in drinking than those experiencing low family conflict.

Findings of the current research indicate that the frequency of alcohol drinking and harmful use of alcohol among the respondents also has a negative impact on their educational attainments. Zalta and collegues (2008) reported that the frequency of alcohol drinking and binging decreases with better academic performance. There is growing evidence that poor school performance is associated also with the abuse of other legal and illegal substances. Can and collegues (2008) argue that satisfactory academic performance may serve as a natural protective factor against risky alcohol-related behaviour.

As a significant correlation was noted between adolescents' alcohol consumption and the adolescents' academic achievement, new policies and strategies to reduce alcohol-related harm should be developed and implemented. According to the draft of the Council conclusions of 1 December 2009 on alcohol and health, all member states should consider further steps to protect children, adolescents and young people from alcohol-related harm, in particular to reduce underage drinking, binge drinking, exposure to alcohol marketing and harm to children growing up in families with alcohol problems. Based on the established data, Akmatov and collegues (2011) concluded that heavy drinking and problem drinking are common among university students. They suggest that intervention programs should be designed for students at a particularly high risk. Similar results and conclusions were reached in the study conducted among the firstyear full-time students of the University of Ljubljana (Biščak, et al., 2011). It is of upmost importance to develop and implement programmes targeting to the reduction of alcohol consumption.
Alcohol may help individuals to relax and adds to their sociability or social intercourse, it temporarily enhances alleviation of stress and acceptance by peers. On the other hand, the consequences of problematic drinking may be serious, damaging and far-reaching. Heavy drinking may lead to the loss of social identity, entailing negative psychological, mental, physical as well as financial consequences. The education institutions can play a crucial role in the protection of young people from short and long-term effects of alcohol and modify their problematic drinking behaviours. They may incorporate contents related to substance abuse into the curricula and initiate the website addressing this issue. The education institutions should assume the responsibility to promote healthy lifestyle and deepen the students' knowledge and awareness of harmful and hazardous use of alcohol and other legal and illegal substances. Similar suggestions were put forward by Durkin (2008), who emphasises the importance of knowledge of alcohol policy and alcohol-related health risks.

The established association between leisure time and alcohol drinking suggests the need for organisation of various group sports activities, which should be available and accessible to all young people. Local communities could develop programmes by which adolescents and young adults may actively participate in challenging, fulfilling and health promoting activities.

A considerable amount of literature has been published in Slovenia and worldwide on various aspects of alcohol consumption, pinpointing the adverse effects of alcohol on health, and the relevance of prevention. The results of the present study along with the proposed preventive measures may nonetheless prove valuable in designing effective interventions related to alcohol consumption in Slovenia. However, with a small size of the random sample (four institutions, full-time students), caution must be applied, as the findings might not be transferable to all undergraduate students of Gorenjska region. As regression models have a small explanatory power, the list of possible reasons for alcohol consumption is not conclusive. The reasons identified in the study include cultural acceptance and expectance of alcohol drinking, availability of alcohol, drinking volume, the commercial communication of alcohol products, and everyday stress.

Contrary to our expectations, the response rate of the potential participants was low. We were surprised by the lack of interest, declination to participate, and the delayed response to our invitation.

\section{Conclusion}

Several risk factors related to student alcohol drinking have been identified. The factors which were most commonly reported by the respondents are social (family support and peer pressure and influence) and individual (poor self-image, poor academic performance, spending 
leisure time). On the other hand, good interpersonal relations (family, peers, school), environmental factors (healthy environment, healthy lifestyle) may reduce drinking frequency, drinking volume and alcoholrelated harm. Public health policy makers, the cultural shift, and health promotion programmes and activities may help reduce the disturbing student alcohol consumption. The development and implementation of appropriate preventive programmes should address the prevention of alcohol-related harm in children and young people. These programmes should also help to develop the adolescents' general social skills. They may contribute to the improvement of self-esteem, and change the adolescent's drinking beliefs, attitudes and drinking behaviours that are assumed to underlie the adolescent drinking. Future research is needed to further substantiate these findings and to identify the effective and targeted measures for the reduction of alcohol misuse. Future research should include the students of various other fields in order to determine the risk factors associated with the students' alcoholrelated health literacy.

\section{Slovenian translation/Prevod v slovenščino}

\section{Uvod}

Alkohol je najbolj pogosto uporabljena dovoljena droga v študentskih letih (Baker \& Boland, 2011). Po podatkih Ministrstva za zdravje (2008) alkohol v svetu predstavlja šesti najpomembnejši vzrok za prezgodnjo umrljivost in obolevnost, $v$ Evropi pa celo tretjega oziroma prvega med mladimi. Uživanje alkohola predstavlja velik zdravstveni problem mladih (Rassool, 2007). Med mladimi je alkohol najbolj razširjena droga, pri čemer poseganje po njem tudi narašča, še zlasti t. i. opijanje (Hovnik Keršmanc, 2010). Problem opijanja je razširjen tudi v drugih državah. Raziskave med študenti v Združenih državah Amerike kažejo, da opijanje povzroča negativne posledice, ki se kažejo v slabšem učnem uspehu in nižjem samospoštovanju (Kazemi, et al., 2011).

Po podatkih Evropske raziskave o alkoholu in preostalih drogah med šolsko mladino ESPAD 2011 (Hibell, et al., 2011) ima v Sloveniji izkušnje s pitjem alkoholnih pijač kar $93 \%$ respondentov. Alkoholne pijače bolj pogosto uživajo fantje kot dekleta (Stergar, 2011). Enako je tudi raziskava med študenti prvih in četrtih letnikov Univerze v Mariboru podala ugotovitev, da bolj pogosto pijejo moški kot ženske (Kolšek \& Klemenc Ketiš, 2015). Alkoholna problematika je prisotna tudi v gorenjski regiji, saj je pitje alkohola razširjeno tako med mladimi kot tudi med odraslimi. Zaskrbljujoče je, da mladi alkoholu pripisujejo bolj pozitivne kot negativne učinke in kot najbolj pozitiven učinek navajajo zabavo (Hovnik Keršmanc, 2011).

Obstaja veliko dejavnikov, ki so vzrok uživanja alkoholnih pijač mladih. Le-ti so predvsem želja po sprejetosti s strani vrstnikov, zunanje okolje, dostopnost alkohola, zapeljivi oglasi, veliko prostega časa. Negativne posledice uživanja alkoholnih pijač vplivajo na počutje študentov, povzročajo "mačka «, zmanjšujejo uspešnost $\mathrm{v}$ izobraževalnem procesu, privedejo do posledic, ki bi jih kasneje obžalovali, do več poškodb, prometnih nesreč in smrti (Snyder, 2006).

Številne raziskave kažejo, da je stres $\mathrm{v}$ zadnjih desetletjih med mladimi zelo povečan, zato je tudi raba alkohola, tobaka in tudi nedovoljenih drog med mladimi zelo razširjena (Varela \& Picakrd, 2011). Na tvegano življenje mladih vplivajo tako vrstniki kot tudi odrasli (Etcheverry \& Agnew, 2008; Kenna \& Lewis, 2008). Mladim so njihovi vrstniki vzor, zato obstaja tudi večja verjetnost, da bodo posegali po alkoholu, če se družijo z vrstniki, ki pijejo alkoholne pijače bolj pogosto, kot če se družijo z vrstniki, ki ne uživajo alkohola (Cicognani \& Zani, 2011). Opazovanje sovrstnikov, ki uživajo alkohol, spodbuja študente $\mathrm{k}$ pitju alkohola, kar posledično vodi do povečane rabe alkohola (Champion, et al., 2015).

Najbolj pogosti dejavniki tveganja za pitje in opijanje mladih so slabše družinske razmere, splošni družbeni kontekst, študijska neuspešnost, odnosi $\mathrm{z}$ vrstniki, zgodnji nastop problematičnega vedenja in uporabe drog ter fiziološki in genetski dejavniki (Maggs \& Schulenberg, 2006). Na popivanje mladih vplivata tudi prisotnost anksioznosti in depresije (McNamara, et al., 2010).

\section{Namen in cilji}

Namen izvedene raziskave je bil analizirati stanje na področju zlorabe alkohola med študenti višje- in visokošolskih zavodov $\mathrm{v}$ gorenjski regiji. $\mathrm{Z}$ raziskavo smo želeli dobiti vpogled $\mathrm{v}$ pivske navade študentov na višje- in visokošolskih zavodih $\mathrm{v}$ gorenjski regiji ter identificirati dejavnike, ki so povezani $z$ uživanjem alkoholnih pijač študentov.

Postavili smo si naslednjo hipotezo:

H1: Uživanje alkohola pri študentih je povezano $\mathrm{z}$ dejavniki, kot so stres, pomanjkanje socialne podpore, občutek boljše sprejetosti v družbi in srednješolski učni uspeh.

\section{Metode}

Raziskava temelji na kvantitativni neeksperimentalni raziskovalni metodi, podatke smo zbirali s tehniko anketiranja, kot instrument smo uporabili strukturirani vprašalnik.

\section{Opis instrumenta}

Strukturirani vprašalnik je vseboval sedem sklopov z različnim številom vprašanj: vprašanja s ponujenimi odgovori, kontrolni seznam in trditve v obliki Likertove lestvice stališč. Posamezne vrednosti te lestvice so bile definirane $\mathrm{z}$ oceno od 1 do 5, kjer je 1 pomenila, da 
se $\mathrm{z}$ navedeno trditvijo sploh ne strinjajo, 2 - se ne strinjajo, 3 - niti se ne strinjajo/niti se strinjajo, 4 se strinjajo, in 5 - se zelo strinjajo. Vprašalnik je bil oblikovan na osnovi pregleda literature različnih avtorjev na področju alkoholne problematike (Watson, et al., 2006; Zalta, et al., 2008; Tremblay, et al., 2010). Zanesljivost vprašalnika smo preverjali $\mathrm{z}$ metodo analize notranje konsistentnosti.

Rezultati o zanesljivosti vprašalnika na vzorcu vključenih v raziskavo so bili naslednji:

- Crohnbachov koeficient alfa za 10 trditev, ki se nanašajo na osebne značilnosti in socialne odnose, je znašal 0,82;

- Crohnbachov koeficient alfa za 8 trditev, ki se nanašajo na posledice uživanja alkohola, je znašal 0,81.

Veljavnost instrumenta smo pojasnili tudi s pomočjo faktorske analize po spremenljivkah. Dosegli smo primerno pojasnitev variance in dobljene faktorje uporabili v nadaljnji statistični analizi, kar prikazujemo v rezultatih. Da bi zmanjšali število spremenljivk, smo $\mathrm{z}$ metodo glavnih komponent (Principal Component Analysis) analizirali njihovo medsebojno soodvisnost, bolj jasno strukturo faktorskih uteži pa smo dobili $\mathrm{z}$ rotacijo faktorjev. $\mathrm{Z}$ analizo glavnih komponent smo tako dobili tri komponente, s katerimi skupno pojasnimo 71,6 \% celotne variabilnosti $(\mathrm{KMO}=0,932$ in Barlett $\mathrm{p}<0,001)$. S faktorjem "pogostost pitja zaradi komunikativnosti in sproščenosti«, v katerega so se uvrstile tri trditve, pojasnimo $47,66 \%$ variance; s faktorjem " pogostost pitja v prostem času «, v katerega so se uvrstile tri trditve, pojasnimo $13,41 \%$ variance in $s$ faktorjem "pitje kot posledica blaženja stresa in težav «, v katerega so se uvrstile štiri trditve, pojasnimo $10,60 \%$ variance. V nadaljnji statistični obdelavi smo uporabili vse tri faktorje.

\section{Opis vzorca}

$\mathrm{V}$ raziskavo smo vključili študente višje- in visokošolskih zavodov na področju gorenjske regije. $\mathrm{V}$ gorenjski regiji so 3 visoko- in 7 višješolskih zavodov. Iz seznama višje- in visokošolskih zavodov smo izločili zavode, ki izvajajo le izredni študij. Tako smo pridobili 5 višje- in 3 visokošolske zavode. Vključili smo 2 višje- in 2 visokošolska zavoda, saj od vseh višje- in visokošolskih zavodov nismo pridobili soglasja za izvedbo raziskave, nekateri pa so bili kljub podanemu soglasju neodzivni oziroma so prepozno oddali termin za izvedbo raziskave. Sodelovali so naslednji (višje- in visokošolski) zavodi: Ekonomskostoritveni izobraževalni center Kranj, Višja strokovna šola; Šolski center Škofja Loka; Fakulteta za zdravstvo Jesenice (FZJ); Fakulteta za organizacijske vede Kranj. Vzorec je bil namenski. V raziskavo FZJ smo vključili dve generaciji rednih študentov prvega letnika, vpisanih v študijskem letu 2011/12 in 2012/13, pri ostalih $\mathrm{v}$ raziskavo vključenih izobraževalnih zavodih pa smo zajeli redne študente prvih letnikov, vpisane
Tabela 1: Število študentov, vpisanih v prvi letnik $v$ študijskem letu 2011/12 oz. 2012/13, in število v raziskavo vključenih študentov po gorenjskih višje- in visokošolskih zavodih

Table 1: The number of the first-year students enrolled in the academic years 2011/12 and 2012/13 and the number of students from higher education institutions in the Gorenjska region who participated in the study

\begin{tabular}{|c|c|c|c|}
\hline $\begin{array}{l}\text { Višje- oz. visokošolski zavod } \\
\text { (̌studijsko leto vpisa)/ } \\
\text { Higher education institution } \\
\text { (academic year enrollment) }\end{array}$ & $n_{1}$ & $n_{2}$ & $\%$ \\
\hline $\begin{array}{l}\text { Ekonomsko-storitveni izobraževalni } \\
\text { center Kranj, Višja strokovna šola } \\
(2012 / 13)\end{array}$ & 91 & 35 & 38,5 \\
\hline Šolski center Škofja Loka (2012/13) & 89 & 67 & 75,3 \\
\hline $\begin{array}{l}\text { Fakulteta za zdravstvo Jesenice } \\
(2011 / 12 ; 2012 / 13)\end{array}$ & 190 & 131 & 68,9 \\
\hline $\begin{array}{l}\text { Fakulteta za organizacijske vede Kranj } \\
(2012 / 13)\end{array}$ & 297 & 95 & 32 \\
\hline Skupaj & 667 & 328 & 49,2 \\
\hline $\begin{array}{l}\text { Legenda/Legend: } n_{1}-\text { stevilo vpisanih } \\
\text { enrolled students; } n_{2} \text { - število študento } \\
\text { caziskavi/the number of students who par } \\
\text { \% - odstotek/percentage }\end{array}$ & & & \\
\hline
\end{tabular}

v študijskem letu 2012/13. V raziskavi je sodelovalo 328 študentov, kar predstavlja 49,2\% realizacijo vzorca (Tabela 1).

Med anketiranimi študenti jih je bilo 64,6 \% starih med 18 in 20 let, le 4,3\% študentov je bilo starih 24 let ali več. Med anketiranci je bilo 147 moških (44, $8 \%)$ in 181 žensk (55,2\%). Največji delež anketiranih študentov je $\mathrm{v}$ zadnjem letniku srednješolskega izobraževanja imelo dober uspeh $(47,6 \%)$, le 3,4 \% anketiranih je imelo odličen uspeh.

\section{Opis poteka raziskave in obdelave podatkov}

Raziskava je potekala maja 2012 in od oktobra do novembra 2012. Vsem sodelujočim višje- in visokošolskim zavodom $\mathrm{v}$ gorenjski regiji smo poslali pismo s prošnjo za soglasje glede izvedbe raziskave in s pojasnili namena, poteka in časa anketiranja. Ko smo soglasja pridobili, smo v dogovoru s koordinatorjem raziskave v posameznih zavodih izvedli anketiranje. Anketirancem smo razložili postopek anketiranja ter počakali, da so izpolnili vprašalnike. Vsem sodelujočim smo zagotovili anonimnost.

Pridobljene podatke smo obdelali s pomočjo računalniškega programa SPSS verzija 20.0 (SPSS, Chicago, IL, USA). Uporabili smo opisno statistiko in analizo povezanosti. Spremenljivke smo oblikovali na osnovi faktorske analize. Za pojasnitev odnosa do alkohola med mladimi smo uporabili linearno multiplo regresijsko analizo. Za statistično pomembne podatke smo upoštevali razlike, kjer je bila stopnja statistične pomembnosti na ravni 0,05 in manj. 


\section{Rezultati}

Iz Tabele 2 je razvidno, da so anketiranci v največjem deležu $(61,3 \%)$ prvo alkoholno pijačo poskusili med 15. in 18. letom starosti, večina preostalih (36 \%) pa med 10. in 14. letom starosti. Ob posamezni pivski priložnosti največ anketiranih študentov (34,5\%) spije največ 3-4 merice alkoholnih pijač, kar 18,3 $\%$ anketirancev pa 7 meric in več. Največji delež študentov $(28,4 \%)$ pije alkoholne pijače ob posebnih priložnostih, tj. nekajkrat na leto, 3-6-krat na teden pa $4,9 \%$ anketirancev.

Zanimalo nas je, ali je uživanje alkohola pri študentih povezano $\mathrm{z}$ dejavniki, kot so pomanjkanje socialne podpore s strani družine, nižja samopodoba, občutek boljše sprejetosti $\mathrm{v}$ družbi med vrstniki ter nižji srednješolski učni uspeh. Rezultati raziskave kažejo, da so študenti deležni socialne podpore $s$ strani družine $(\bar{X}=4,3, s=0,8)$, medtem ko zadovoljstvo s samopodobo ocenjujejo s povprečno vrednostjo $3,8(s=0,8)$ (ocenjeno po petstopenjski Likertovi lestvici).

Uporabili smo regresijsko analizo, s katero smo ugotavljali medsebojno odvisnost med več spremenljivkami, ki so bile medsebojno povezane. Zgradili smo tri regresijske modele $\mathrm{z}$ neodvisnimi in odvisnimi spremenljivkami, ki so bile dobljene s faktorsko analizo: pogostost pitja zaradi komunikativnosti in sproščenosti, pitje $\mathrm{v}$ prostem času ter pitje kot posledica stresa in težav.

Povprečna vrednost faktorja "pogostost pitja zaradi komunikativnosti in sproščenosti« je bila 3,5 $(s=1,1)$, faktorja "pogostost pitja v prostem času « $3,2(s=0,9)$ in faktorja "pitje kot posledica blaženje stresa in težav" $2,2(s=0,8)$.

Iz Tabele 3 razberemo, da imajo dejavniki: zadovoljstvo s samopodobo $(\beta=-0,126, p=0,020)$, povprečni učni uspeh $\mathrm{v}$ zadnjem letniku srednješolskega izobraževanja $(\beta=0,168, p=0,002)$, pogostost izvajanja gibalne aktivnosti (vsaj 30 minut na dan) ( $\beta$ $=-0,093, p=0,045)$, gledanje televizije $\mathrm{v}$ prostem času $(\beta=0,118, p=0,028)$ in preživljanje prostega časa $s$ prijatelji $(\beta=-0,139, p=0,011)$ statistično pomemben vpliv na pogostost pitja zaradi komunikativnosti in sproščenosti. Ti dejavniki pojasnijo 8,1 \% celotne variabilnosti pogostosti pitja zaradi komunikativnosti in sproščenosti. Največji vpliv na pogostost pitja ima povprečni učni uspeh $\mathrm{v}$ zadnjem letu srednješolskega izobraževanja $(\beta=0,168)$.

$\mathrm{Z}$ regresijsko analizo smo ugotovili (Tabela 4) statistično pomemben vpliv posameznih preučevanih spremenljivk na pogostost pitja alkoholnih pijač $\mathrm{v}$ prostem času, pri tem gre za naslednje spremenljivke:zadovoljstvo s samopodobo

Tabela 2: Značilnosti anketiranih študentov $v$ zvezi $z$ alkoholom

Tabel 2: Characteristics of the students in relation to alcohol consumption

\begin{tabular}{|c|c|c|}
\hline Trditve/The arguments & $n$ & $\%$ \\
\hline $\begin{array}{l}\text { Najljubša pijača } \\
\text { Żgane pijače } \\
\text { Pivo } \\
\text { Vino } \\
\text { Pijače alkopop - ustekleničene sladke pijače s približno } 5 \% \text { vsebnostjo alkohola } \\
\text { Skupaj }\end{array}$ & $\begin{array}{l}101 \\
90 \\
81 \\
53 \\
325\end{array}$ & $\begin{array}{l}30,8 \\
27,4 \\
24,7 \\
17,1 \\
100\end{array}$ \\
\hline $\begin{array}{l}\text { Starost ob prvem zaužitju alkoholne pijače } \\
\text { Nikoli } \\
\text { Med 10. in 14. letom } \\
\text { Med 15. in 18. letom } \\
\text { Med 19. in 22. letom } \\
\text { Skupaj }\end{array}$ & $\begin{array}{l}1 \\
118 \\
201 \\
8 \\
328\end{array}$ & $\begin{array}{l}0,3 \\
36,0 \\
61,3 \\
2,4 \\
100\end{array}$ \\
\hline $\begin{array}{l}\text { Količina običajno popite alkoholne pijače ob posamezni pivski priložnosti } \\
\text { Ne pijem alkoholnih pijač } \\
1-2 \text { merici } \\
3-4 \text { merice } \\
5-6 \text { meric } \\
7 \text { meric in več } \\
\text { Skupaj }\end{array}$ & $\begin{array}{l}14 \\
84 \\
113 \\
55 \\
60 \\
326 \\
\end{array}$ & $\begin{array}{l}4,3 \\
25,6 \\
34,5 \\
17,3 \\
18,3 \\
100\end{array}$ \\
\hline $\begin{array}{l}\text { Pogostost pitja alkoholnih pijač v zadnjem letu } \\
\text { Nikoli } \\
\text { Nekajkrat na leto, ob posebnih priložnostih } \\
\text { 1-krat na mesec } \\
\text { 2-3-krat na mesec } \\
\text { 1-2-krat na teden } \\
\text { 3-6-krat na teden } \\
\text { Vsak dan } \\
\text { Skupaj }\end{array}$ & $\begin{array}{l}11 \\
93 \\
59 \\
82 \\
64 \\
16 \\
3 \\
328\end{array}$ & $\begin{array}{l}3,4 \\
28,4 \\
18,0 \\
25,0 \\
19,5 \\
4,9 \\
0,9 \\
100\end{array}$ \\
\hline
\end{tabular}

Legenda/Legend: $n$ - število/number; \% - odstotek/percentage 
Tabela 3: Rezultati regresijske analize pogostosti pitja zaradi komunikativnosti in sproščenosti Tabel 3: Results of regression analysis of frequency of alcohol consumption for better sociability and relaxation

\begin{tabular}{|c|c|c|c|c|c|}
\hline $\begin{array}{l}\text { Pogostost pitja zaradi } \\
\text { komunikativnosti in } \\
\text { sproščenosti/ } \\
\text { Drinking as a result } \\
\text { of stress and problems }\end{array}$ & $\begin{array}{l}\text { Značilnosti/ } \\
\text { Characteristics }\end{array}$ & $b$ & $\beta$ & $t$ & $p$ \\
\hline \multirow{6}{*}{$\begin{array}{l}\mathrm{R}=0,308 \\
\mathrm{R}^{2}=0,095 \\
\text { pril. } \mathrm{R}^{2}=0,081\end{array}$} & Konstanta & 0,213 & I & 0,530 & 0,596 \\
\hline & Zadovoljen/-a sem s samopodobo. & $-0,141$ & $-0,126$ & $-2,330$ & 0,020 \\
\hline & $\begin{array}{l}\text { Povprečni učni uspeh v zadnjem letniku } \\
\text { srednješolskega izobraževanja }\end{array}$ & 0,238 & 0,168 & 3,130 & 0,002 \\
\hline & $\begin{array}{l}\text { Kako pogosto se ukvarjate z gibalno } \\
\text { aktivnostjo (vsaj } 30 \text { minut na dan)? }\end{array}$ & $-0,071$ & $-0,093$ & $-2,013$ & 0,045 \\
\hline & Kako pogosto v prostem času gledate TV? & 0,140 & 0,118 & 2,202 & 0,028 \\
\hline & $\begin{array}{l}\text { Kako pogosto greste v prostem času s } \\
\text { prijatelji ven (na kavo, zabavo)? }\end{array}$ & $-0,196$ & $-0,139$ & $-2,572$ & 0,011 \\
\hline
\end{tabular}

Legenda/Legend: $b$ - regresijski koeficient/regression coefficient; $\beta$ - standardizirani regresijski koeficient/standardized regression coefficient; $R$ - korelacijski koeficient/the correlation coefficient; $R 2$ - povprečje vseh skupnih dosežkov/the average of all the total achievements; pril. $R^{2}$ - delež pojasnjevalne variabilnosti/the explanatory proportion of variability; $t$ - vrednost koeficienta/coefficient value; $p$ - statistična značilnost/statistical significance

Tabela 4: Rezultati regresijske analize pogostosti pitja $v$ prostem času

Tabel 4: Results of regression analysis of frequency of alcohol consumption in the respondents' leisure time

\begin{tabular}{|c|c|c|c|c|c|}
\hline $\begin{array}{l}\text { Pogostost pitja } v \text { prostem } \\
\text { času/ } \\
\text { Frequency of drinking in the } \\
\text { respondents' leisure time }\end{array}$ & $\begin{array}{l}\text { Značilnosti/ } \\
\text { Characteristics }\end{array}$ & $\boldsymbol{b}$ & $\beta$ & $t$ & $p$ \\
\hline \multirow{9}{*}{$\begin{array}{l}\mathrm{R}=0,463 \\
\mathrm{R}^{2}=0,214 \\
\text { pril. } \mathrm{R}^{2}=0,194\end{array}$} & Konstanta & $-0,384$ & 1 & $-0,799$ & 0,425 \\
\hline & Zadovoljen/-a sem s samopodobo. & 0,104 & 0,093 & 1,676 & 0,045 \\
\hline & Imam veliko prijateljev. & 0,146 & 0,131 & 2,198 & 0,029 \\
\hline & S prijatelji se pogosto družimo. & 0,148 & 0,127 & 2,123 & 0,035 \\
\hline & V primeru težav mi oporo nudi družina. & $-0,207$ & $-0,183$ & $-3,456$ & 0,001 \\
\hline & $\begin{array}{l}\text { V primeru težav oporo poiščem pri } \\
\text { visokošolskih učiteljih. }\end{array}$ & $-0,201$ & $-0,195$ & $-3,873$ & 0,000 \\
\hline & $\begin{array}{l}\text { Povprečni učni uspeh v zadnjem letniku } \\
\text { srednješolskega izobraževanja }\end{array}$ & 0,138 & 0,098 & 1,944 & 0,043 \\
\hline & $\begin{array}{l}\text { Kako pogosto greste v prostem času } \mathrm{v} \\
\text { naravo? }\end{array}$ & 0,117 & 0,098 & 1,933 & 0,044 \\
\hline & $\begin{array}{l}\text { Kako pogosto greste v prostem času s } \\
\text { prijatelji ven (na kavo, zabavo)? }\end{array}$ & $-0,315$ & $-0,224$ & $-4,160$ & 0,000 \\
\hline
\end{tabular}

Legenda/Legend: $b$ - regresijski koeficient/regression coefficient; $\beta$ - standardizirani regresijski koeficient/standardized regression coefficient; $R$ - korelacijski koeficient/the correlation coefficient; $R^{2}$ - povprečje vseh skupnih dosežkov/the average of all the total achievements; pril. $R^{2}$ - delež pojasnjevalne variabilnosti/the explanatory proportion of variability; $t$ - vrednost koeficienta/coefficient value; $p$ - statistična značilnost/statistical significance

$(\beta=0,093, p=0,045)$, prijateljstvo $(\beta=0,131, p=$ $0,029)$, pogosto druženje s prijatelji $(\beta=0,127, p=$ $0,035)$, opora družine v primeru težav $(\beta=-0,183$, $p=0,001)$, opora učiteljev $\mathrm{v}$ primeru težav $(\beta=$ $-0,195, p=0,000)$, povprečni učni uspeh $\mathrm{v}$ zadnjem letu srednješolskega izobraževanja $(\beta=0,098, p=$ $0,043)$, preživljanje prostega časa v naravi $(\beta=0,098$, $p=0,044)$ in preživljanje prostega časa $s$ prijatelji $(\beta=-0,224, p=0,000)$. Ti dejavniki pojasnijo 19,4 $\%$ celotne variabilnosti pogostosti pitja alkoholnih pijač med počitnicami in konec tedna.
Rezultati kažejo (Tabela 5), da na pogostost pitja kot posledico blaženja stresa in težav statistično pomembno vpliva opora družine $(\beta=-0,165, p=$ $0,003)$, povprečni učni uspeh $\mathrm{v}$ zadnjem letniku srednješolskega izobraževanja $(\beta=0,186, p=0,000)$, preživljanje prostega časa v nakupovalnih središčih $(\beta=-0,115, p=0,033)$, preživljanje prostega časa $s$ prijatelji $(\beta=-0,131, p=0,022)$. Dejavniki pojasnijo $12 \%$ celotne variabilnosti pogostosti pitja ob izpitih in delavnikih, s katerim študenti rešujejo stres in težave. 
Tabela 5: Rezultati regresijske analize pitja kot posledice blaženja stresa in težav

Tabel 5: Results of regression analysis of the consequences of drinking due to stress and other problems

\begin{tabular}{|c|c|c|c|c|c|}
\hline $\begin{array}{l}\text { Pitje kot posledica blaženja } \\
\text { stresa in težav/ } \\
\text { Drinking as a result of } \\
\text { mitigating the stress and } \\
\text { problems }\end{array}$ & $\begin{array}{l}\text { Značilnosti/ } \\
\text { Characteristics }\end{array}$ & $b$ & $\beta$ & $t$ & $p$ \\
\hline \multirow{6}{*}{$\begin{array}{l}\mathrm{R}=0,373 \\
\mathrm{R}^{2}=0,139 \\
\text { pril. } \mathrm{R}^{2}=0,120\end{array}$} & Konstanta & $-0,255$ & I & $-0,484$ & 0,629 \\
\hline & S prijatelji se pogosto družimo. & 0,131 & 0,113 & 1,958 & 0,051 \\
\hline & V primeru težav mi oporo nudi družina. & $-0,186$ & $-0,165$ & $-3,032$ & 0,003 \\
\hline & $\begin{array}{l}\text { Povprečni učni uspeh v zadnjem letniku } \\
\text { srednješolskega izobraževanja }\end{array}$ & 0,263 & 0,186 & 3,520 & 0,000 \\
\hline & $\begin{array}{l}\text { Kako pogosto v prostem času obiskujete } \\
\text { nakupovalne centre s prijatelji? }\end{array}$ & $-0,172$ & $-0,115$ & $-2,138$ & 0,033 \\
\hline & $\begin{array}{l}\text { Kako pogosto greste v prostem času s } \\
\text { prijatelji ven (na kavo, zabavo)? }\end{array}$ & $-0,184$ & $-0,131$ & $-2,295$ & 0,022 \\
\hline
\end{tabular}

Legenda/Legend: $b$ - regresijski koeficient/regression coefficient; $\beta$ - standardizirani regresijski koeficient/standardized regression coefficient; $R$ - korelacijski koeficient/the correlation coefficient; $R 2$ - povprečje vseh skupnih dosežkov/the average of all the total achievements; pril. $R^{2}$ - delež pojasnjevalne variabilnosti/the explanatory proportion of variability; $t$ - vrednost koeficienta/coefficient; p-statistična značilnost/statistical significance

\section{Diskusija}

Da bi izpostavili dejavnike tveganja za uživanje alkohola pri študentih, smo najprej želeli pridobiti mnenja o odnosu in značilnostih študentov $\mathrm{v}$ povezavi $\mathrm{z}$ uživanjem alkoholnih pijač. Ugotovili smo, da je alkohol tudi $\mathrm{v}$ naši raziskovani populaciji dokaj razširjen: da alkoholnih pijač nikoli ni pilo, je npr. odgovorilo le 4,3\% anketirancev. Lahko trdimo, da je prisotnost alkohola pri študentih visoka, kar posledično lahko povzroča tveganja, povezana s pitjem alkoholnih pijač. $\mathrm{V}$ visokem deležu so anketiranci prvo alkoholno pijačo poskusili med 10. in 14. letom starosti, kar ne odstopa od povprečnega slovenskega mladostnika. Povprečni slovenski mladostnik je ob prvem uživanju alkoholne pijače star 13 let (Inštitut za varovanje zdravja, 2010). Ugotovljen visok odstotek tveganega in škodljivega pitja in opijanja je bil tudi med študenti Univerze v Ljubljani (Biščak, et al., 2014).

Najbolj priljubljene alkoholne pijače anketiranih študentov predstavljajo žgane pijače in nato pivo. Po podatkih raziskave ESPAD 2011 je v večini držav pivo glavna pijača med fanti, medtem ko so $\mathrm{v}$ nekaj več kot $\mathrm{v}$ polovici držav žgane pijače bolj priljubljena pijača med dekleti. Pivo in žgane pijače predstavljajo približno $70 \%$ celotne porabe alkoholnih pijač (Hibell, et al., 2011). Pitje med mladostniki narašča po vsej Evropi, mladina v Sloveniji se čedalje pogosteje opija. Izsledki raziskav kažejo, da so razlogi, zaradi katerih mladostniki segajo po alkoholnih pijačah, številni: uživanje alkoholnih pijač kot način zabave in sprostitve, večja komunikativnost, lažje navezovanje stikov, velja samozavest oziroma boljša samopodoba, doživljanje sreče, občutek boljše sprejetosti med starejšimi sovrstniki, poistovetenje s svojimi vzorniki (Jeriček Klanšček, et al., 2007).
Rezultati naše raziskave so pokazali, da so dejavniki, ki so povezani $z$ uživanjem večjih količin alkoholnih pijač zaradi vzpostavljanja komunikacije in boljše sproščenosti, slabši povprečni uspeh, nižja samopodoba, bolj pogosto druženje s prijatelji. Watson in sodelavci (2006) ugotavljajo, da uživanje alkoholnih pijač študentov v Veliki Britaniji povzroča občutek dobrega počutja, zaradi česar so mladi v družbi bolj sproščeni in družabni. Za današnje mlade je značilno, da se sprostijo in zabavajo pod vplivom alkohola. Dokler še niso omamljeni, so praviloma zadržani, ko pa se opijejo, postanejo bolj odprti in sproščeni in se radi bahajo s svojimi uspehi. Opijanje v družbi torej sprosti zavore za dejanja, ki jih v treznem stanju ti mladi ne bi počeli (Ramovš \& Ramovš, 2007). Tudi Hibell in sodelavci (2011) ugotavljajo, da večina študentov alkohol uživa zaradi zabave in da bi pozabili na svoje probleme.

$\mathrm{Z}$ izvedeno raziskavo ugotavljamo, da bolj ko so študenti nezadovoljni s samopodobo, bolj posegajo po alkoholnih pijačah. Številni dejavniki vplivajo na razvoj samopodobe mladih. Samopodoba je dejavnik, ki vpliva na kakovost življenja, odnosov in sposobnosti posameznika.

Ugotovili smo, da slabši uspeh v šoli, manjša opora $\mathrm{v}$ družini in druženje s prijatelji vplivajo na pogostost pitja alkoholnih pijač. Vsekakor obstajajo tudi drugi dejavniki, ki jih $\mathrm{v}$ raziskavi nismo proučevali. Predvidevamo lahko, da študenti pogosto pijejo alkoholne pijače, ker so te lahko dostopne in tudi družbeno sprejemljive. Dostopnost alkohola izhaja velikokrat iz domačega okolja, kjer mladi odraščajo. Raziskave kažejo na to, da se mladostniki s prvo izkušnjo pitja alkohola pogosto srečajo $\mathrm{v}$ domačem okolju (Anderson \& Baumberg, 2006), kar v Sloveniji glede na razširjeno (domačo) proizvodnjo alkoholnih 
pijač ter vpetost alkohola $\mathrm{v}$ kulturo niti ni posebno nenavadno (Bajt \& Zorko, 2006). Menimo, da bi poleg prepovedi potrebovali tudi druge ukrepe, $s$ katerimi bi vplivali na zmanjševanje dostopnosti do alkohola. Mlade bi morali spodbujati k izvajanju brezalkoholnih programov, obveščanje in ozaveščanje o škodljivih učinkih alkohola bi bilo treba vzpostaviti tudi preko družbenih omrežij ter mlade vključevati $\mathrm{v}$ zdravstvenovzgojne delavnice. Študentske in nevladne organizacije že izvajajo vrsto programov in projektov, ki so namenjeni ciljni populaciji mladih. Znana sta "Sporočilo v steklenici« in " $Z$ glavo na zabavo«. Makivić in sodelavci (2013) menijo, da bi glede na dostopnost do alkohola potrebovali ukrepe za zmanjševanje dostopnosti do alkohola. Med ukrepi, ki se v Sloveniji že izvajajo, so se kot učinkoviti izkazali zvišanje cen alkohola, omejevanje dostopov do barov in spodbujanje nadzora nad porabo alkohola $\mathrm{v}$ študentskih domovih.

$\mathrm{V}$ naši raziskavi smo ugotovili, da je $\mathrm{v}$ primeru težav, s katerimi se študenti soočajo, pogostost pitja alkoholnih pijač negativno povezana $\mathrm{z}$ nudenjem opore znotraj družine. Manj opore s strani družine študenti imajo, bolj pogosto pijejo alkoholne pijače. Dejstvo je, da družina predstavlja temeljni proces $\mathrm{v}$ fazi odraščanja. Bolj kot se $\mathrm{v}$ družini pogovarjajo o dejavnikih tveganja, manjša je možnost za uživanje in opijanje študentov $\mathrm{z}$ alkoholnimi pijačami. Dobri medsebojni odnosi $\mathrm{v}$ družini tako predstavljajo varovalni dejavnik, ki vpliva na uživanje alkohola mladih. Da pozitivni odnosi med starši in mladostniki pozitivno vplivajo na zmanjševanje pogostosti pitja alkoholnih pijač menijo tudi Osler in sodelavci (2006) ter avtorja Choo in Shek (2013), ki pravijo, da konflikti $\mathrm{v}$ družini, pivsko vedenje staršev in struktura družine vplival na pivsko vedenje mladih, saj so mladi, ki so prihajali iz družin, kjer so imeli pogoste konflikte, bolj pogosto posegali po alkoholnih pijačah kot tisti, kjer so imeli manj konfliktnih situacij.

Ugotavljamo, da je prisotnost pitja alkoholnih pijač višja pri slabšem povprečnem uspehu anketirancev. Zalta in sodelavci (2008) navajajo, da $\mathrm{z}$ višanjem šolske uspešnosti upada pogostost pitja alkohola in pogostost opijanja z alkoholom. Nižja šolska uspešnost je povezana tudi s poseganjem po drugih dovoljenih in po nedovoljenih drogah. Can in sodelavci (2008) menijo, da so uspehi $\mathrm{v}$ času študija lahko naravni varovalni dejavnik pred tveganim vedenjem mladih $\mathrm{v}$ odnosu do alkohola in ostalih drog.

Ker škodljivo uživanje alkohola med mladostniki negativno vpliva na doseženo stopnjo izobrazbe, je treba preučiti nadaljnje korake za zaščito mladostnikov pred škodo zaradi uživanja alkohola. Skupni cilj je predvsem zmanjšati uživanje alkohola pri mladoletnikih, popivanje, izpostavljenost trženju alkohola in škodo, storjeno otrokom, ki odraščajo v družinah $\mathrm{s}$ problemi, povezanimi $\mathrm{z}$ alkoholizmom (Osnutek sklepov Sveta z dne 1. decembra 2009 o alkoholu in zdravju, 2009). Akmatov in sodelavci (2011) glede na ugotovljeno prekomerno uživanje alkoholnih pijač med študenti prav tako poudarjajo pomen razvijanja programov za mlade s poudarkom na preprečevanju uživanja alkoholnih pijač. Potrebe po razvoju preventivnih programov, s katerimi bi vplivali na zmanjševanje porabe alkohola, so ugotovljene tudi v raziskavi, izvedeni med študenti prvih letnikov rednega študija Univerze v Ljubljani (Biščak, et al., 2011).

Uživanje alkohola lahko sprošča, povečuje komunikativnost, zmanjšuje stres, vpliva na sprejetost med sovrstniki. Toda alkohol je tudi droga, ki lahko vodi $\mathrm{v}$ izgubo na področju socialne identitete, uživanje alkohola ima lahko psihične, duševne in telesne posledice ter lahko povzroči finančne izgube. Za zaščito študentov pred škodljivimi vplivi alkohola morajo $\mathrm{k}$ reševanju alkoholne problematike pristopiti tudi izobraževalni zavodi, saj tudi samo študijsko okolje lahko predstavlja varovalni dejavnik pred zlorabo alkohola. Na področju izobraževalnih zavodov predlagamo vključitev vsebin $s$ področja alkoholne problematike ter ostalih dovoljenih in nedovoljenih drog $\mathrm{v}$ kurikulume ter razvoj spletnih strani, ki bi študentom nudile koristne informacije o zdravem življenjskem slogu. Mlade je treba seznanjati $z$ nevarnostmi, tveganji in obvladovanjem tveganj, povezanih z uživanjem alkoholnih pijač ter ostalih dovoljenih in nedovoljenih drog. Durkin (2008) ugotavlja, da bi v izobraževalnih zavodih v pedagoški proces morali vključevati pridobivanje in razširjanje znanja s področja alkoholne politike, pri čemer bi študentom podajali informacije o zlorabi alkohola in posledicah, ki jih le-ta povzroča.

Glede na povezavo prostega časa in uživanja alkohola predlagamo tudi organizacijo več skupinskih gibalnih aktivnostih, ki bi bile dostopne vsem mladim, saj bi tako lahko aktivno preživljali prosti čas. Predlagamo večjo aktivacijo lokalnih okolij na področju aktivnosti, s katerimi bi mladim omogočali zdravo in aktivno preživljanje prostega časa. Gibalne aktivnosti bi lahko uvedli tudi na višje- in visokošolskih zavodih v okviru predmeta športna vzgoja.

Zavedamose, daje bilona raziskovanotemonarejenih veliko raziskav takov Slovenijikot tudiv mednarodnem prostoru, vendar želimo $\mathrm{z}$ analizo stanja in s spoznanji raziskave seznaniti širok krog javnosti ter s priporočili ukrepov vplivati na zajezitev družbenega problema. Pri sami interpretaciji rezultatov je treba upoštevati omejitve raziskave. V vzorec smo želeli zajeti vse višjein visokošolske zavode $\mathrm{v}$ gorenjski regiji, ki izvajajo redni študij, vendar smo zajeli le štiri šolske zavode, kar vsekakor ni dovolj, da bi rezultate posploševali na celotno populacijo študentov gorenjske regije. V raziskavo smo zajeli nenaključni vzorec. Regresijski modeli imajo majhno stopnjo pojasnjevanja, zato kot omejitev navajamo, da razloge uživanja alkoholnih pijač lahko iščemo tudi drugje. Predvidevamo lahko, 
da so vzroki lahko dostopnost alkohola, alkohol kot družbeno sprejeta droga, vpliv medijev, zapeljivi oglasi, prisotnost stresnega življenja. Pri sami raziskavi smo naleteli na nekaj ovir. Predvidevali smo večjo odzivnost, interes in hitrejšo terminsko uskladitev povabljenih visokošolskih zavodov, ki smo jih želeli vključiti v raziskavo. Presenetilo nas je, da nekateri višje- oziroma visokošolski zavodi $\mathrm{v}$ raziskavi niso želeli sodelovati.

\section{Zaključek}

Razlogov oziroma dejavnikov, zakaj študenti posegajo po alkoholu, je več. Kot pogoste dejavnike tveganja za uživanje alkoholnih pijač pri študentih $\mathrm{v}$ gorenjski regiji izpostavljamo socialne (opora družine), vrstniške (vpliv vrstnikov) in individualne dejavnike tveganja (nizka samopodoba, slabši učni uspeh in preživljanje prostega časa). $\mathrm{Na}$ podlagi opredeljenih dejavnikov tveganja ocenjujemo, da pomembne varovalne dejavnike predstavljajo medosebni odnosi (opora družine, vrstniki, šola) in dejavniki okolja (zdravo okolje, omogočanje zdravega način preživljanja prostega časa). Glede na ugotovljeno stanje in izpostavljene dejavnike tveganja za uživanje alkoholnih pijač pri študentih menimo, da je zelo pomembna krepitev sodelovanja med različnimi akterji na področju alkoholne politike in spodbujanje promocijskih preventivnih aktivnosti. Ker je alkoholna problematika med mladimi razširjena, si ne smemo zatiskati oči, temveč moramo ustrezno pristopiti k reševanju družbenega problema. Z izvajanjem preventivnih aktivnosti in ukrepov lahko vplivamo na zmanjševanje škodljive rabe alkoholnih pijač ter tako mlade usmerjamo k oblikovanju lastne identitete, pozitivne samopodobe ter oblikovanju pozitivnih stališčdo nepitja alkohola. Izsledki raziskave odpirajo nadaljnja zanimiva in uporabna področja raziskovanja. Nadaljnje raziskave bi bile smiselne na področju ugotavljanja pogostosti uživanja alkoholnih pijač ter ugotavljanja dejavnikov tveganja ob izvajanju ciljanih ukrepov za preprečevanje zlorabe alkoholnih pijač. Glede na različne strokovne smeri izobraževanja predlagamo tudi izvedbo raziskave med študenti $\mathrm{z}$ ugotavljanjem dejavnikov tveganja glede na študijski program.

\section{Conflict of interest/Nasprotje interesov}

The authors declare that no conflicts of interest exist./ Avtorji članka izjavljajo, da ni nasprotja interesov.

\section{Funding/Financiranje}

The study received no funding./Raziskava ni bila finančno podprta.

\section{Ethical approval/Etika raziskovanja}

The study was conducted in accordance with the Helsinki-Tokyo Declaration (World Medical Association, 2013) and the Code of ethics for nurses and nurse assistants of Slovenia (2014)./Raziskava je pripravljena v skladu z načeli Helsinško-Tokijske deklaracije (World Medical Association, 2013) in v skladu s Kodeksom etike v zdravstveni negi in oskrbi Slovenije (2014).

\section{Literature/Literatura}

Akmatov, M.K., Mikolajczyk, R.T., Meier, S. \& Kramer, A., 2011. Alcohol consumption among university students in North RhineWestphalia, Germany-results from a multicenter cross-sectional study. Journal of American College Health, 59(7), pp. 620-626.

http://dx.doi.org/10.1080/07448481.2010.520176

PMid:21823957

Anderson, P. \& Baumberg, B., 2006. Alcohol in Europe, a public health perspective: a report for the European Commision. Avaliable at: http://ec.europa.eu/health/archive/ph determinants/life style/alcohol/documents/alcohol europe en.pdf [2. 6. 2016].

Bajt, M. \& Zorko, M., 2009. Pregled glavnih političnih dokumentov $s$ področja alkohola $v$ mednarodnem prostoru in $v$ Sloveniji. Ljubljana: Inštitut za varovanje zdravja Republike Slovenije.

Baker, K. \& Boland, K., 2011. Assessing safety: a campus-wide initiative. College Student Journal, 45(4), pp. 683-699.

Biščak Hafner, M., Kolšek, M. \& Rebek, K., 2014. Pitje alkohola študentov Univerze v Ljubljani. Zdravstveno varstvo, 53(3), pp. 255-261.

http://dx.doi.org/10.1515/sjph-2015-0034

PMid:27647411; PMCid:PMC4820203

Can, G., Ozdilli, K., Erol, O., Unsar, S., Tulek, Z., Savaser, S., et al., 2008. Comparison of the health-promoting lifestyles of nursing and non-nursing students in Istanbul, Turkey. Nursing and Health Sciences, 10(4), pp. 273-280.

http://dx.doi.org/10.1111/j.1442-2018.2008.00405.x

PMid:19128303

Champion, D.A., Lewis, T.F. \& Myers, J.E., 2015. College student alcohol use and abuse: social norms, health beliefs, and selected socio-demographic variables as explanatory factors. Journal of Alcohol and Drug Education, 59(1), pp. 57-82.

Choo, H. \& Shek, D., 2013. Quality of parent-child relationship, family conflict, peer pressure, and drinking behaviors of adolescents in an Asian context: the case of Singapore. Social Indicators Research, 110(3), pp. 1141-1157.

http://dx.doi.org/10.1007/s11205-011-9977-4 
Cicognani, E. \& Zani, B., 2011. Alcohol use among Italian university students: the role of sensation seeking, peer group norms and self-efficacy. Journal of Alcohol and Drug Education, 55(2), pp. 17-36.

Durkin, A., 2008. Educating nursing students about the dangers of drinking games. Nursing education perspectives, 29(1), pp. 38-41. PMid:18330421

Etcheverry, P.E. \& Agnew, C.R., 2008. Romantic partner and friend influences on young adult cigarette smoking: comparing close others' smoking and injunctive norms over time. Psychology of Addictive Behaviors, 22(3), pp. 313-325. http://dx.doi.org/10.1037/0893-164X.22.3.313

PMid:18778125

Hibell, B., Guttormsson, U., Ahlström, S., Balakireva, O., Bjarnason, T., Kokkevi, A., et al., 2011. The 2011 ESPAD report. Available at: http://www.can.se/contentassets/8d8cb78bbd28493b9030c65c 598e3301/the 2011 espad report full.pdf [8. 8. 2015].

Hovnik Keršmanc, M., 2010. Epidemiologija rabe alkohola v Sloveniji. In: I. Avberšek Lužnik, B.M. Kaučič, S. Hvalič Touzery, B. Skela Savič, I. Grmek Košnik \& A. Čufar, eds. Sindrom odvisnosti od alkohola - diagnostični in terapevtski vidiki: zbornik prispevkov z recenzijo, Bled, 13. oktober 2010. Jesenice: Visoka šola za zdravstveno nego, pp. 47-55.

Hovnik Keršmac, M., 2011. Pobuda mestnemu svetu občine Kranj $k$ sprejemanju in izvajanju aktivnosti na področju zmanjševanja škode zaradi alkohola. Kranj: Mestna občina Kranj - Lex localis. Available at: http://www.lex-localis.info/files/862eb4d8-e95e-47ff-9f8387e5c498d05a/7615718259240000000 8.\%20Aktivnosti\%20 na $\% 20$ podrocju $\% 20$ zmanjsevanja $\% 20$ skode $\% 20$ zaradi $\% 20$ alkohola.pdf [21. 6. 2016].

Inštitut za varovanje zdravja Republike Slovenije, 2010. Zdravje v Sloveniji: Tvegano in škodljivo pitje alkohola. Available at: http://www.nijz.si/sites/www.nijz.si/files/publikacije-datoteke/ zdravje v slovenji.pdf [30.3. 2015].

Jeriček Klanšček, H., Lavtar, D. \& Pokrajac, T. eds. 2007. Z zdravjem povezano vedenje $v$ šolskem obdobju: HBSC Slovenija 2006. Ljubljana: Inštitut za varovanje zdravje.

Kazemi, D.M., Wagenfeld, M., Van Horn, K.R., Levine, M.J. \& Dmochowski, J., 2011. Binge drinking among underage college students: role of impulsivity and the Transtheoretical model drinking. Journal of Addictions Nursing, 22(4), pp. 193-199. http://dx.doi.org/10.3109/10884602.2011.616605

Kenna, G.A. \& Lewis, D.C., 2008. Risk factors for alcohol and other drug use by healthcare professionals. Substance Abuse Treatment, Prevention, and Policy, 3, p. 3. http://dx.doi.org/10.1186/1747-597X-3-3 PMid:18230139; PMCid:PMC2265282
Kodeks etike $v$ zdravstveni negi in oskrbi Slovenije in Kodeks etike za babice Slovenije, 2014. Ljubljana: Zbornica zdravstvene in babiške nege Slovenije - Zveza strokovnih društev medicinskih sester, babic in zdravstvenih tehnikov Slovenije.

Kolšek, M. \& Klemenc Ketiš, Z., 2015. Alcohol drinking among the students of the University of Maribor, Slovenia. Zdravstveno varstvo, 54(4), pp. 1-7.

http://dx.doi.org/10.1515/sjph-2015-0034

PMid:27647411; PMCid:PMC4820203

Maggs, L.J. \& Schulenberg, E.J., 2006. Initiation and course of alcohol consumption among adolescents and young adults. In: M. Galanter, ed. Alcohol problems in adolescents and young adults: epidemiology, neurobiology, prevention and treatment. New York: Springer, pp. 29-47.

Makivić, I., Kersnik, J. \& Kolšek, M., 2013. Ukrepi za zmanjševanje tveganega in škodljivega pitja alkohola v populaciji študentov: sistematični pregled literature. Zdravstveno varstvo, 52(3), pp. 236-246.

https://doi.org/10.2478/sjph-2013-0024

McNamara, R.S., Swaim, R.C. \& Rosén, L.A., 2010. Components of negative affect as moderators of the relationship between early drinking onset and binge-drinking behavior. Journal of Child and Adolescence Substance Abuse, 19(2), pp. 108-121. http://dx.doi.org/10.1080/10678281003634884

Ministrstvo za zdravje, 2008. Poročilo o stanju na področju alkohola in alkoholne politike $v$ Sloveniji in Evropi. Ljubljana: Ministrstvo za zdravje, Direktorat za javno zdravje.

Osler, M., Nordentoft, M. \& Andersen, A.N., 2006. Childhood social environment and risk of drug and alcohol abuse in a cohort of Danish men born in 1953. American Journal of Epidemiology, 163(7), pp. 654-661.

http://dx.doi.org/10.1093/aje/kwj084

PMid:16443802

Osnuteksklepov Sveta z dne 1. decembra 2009 o alkoholu in zdravju, 2009. Uradni list Evropske unije, 2009/C 302/07. Available at: http://eur-lex.europa.eu/LexUriServ/LexUriServ.do?uri=OJ:C: 2009:302:0015:0018:SL:PDF [5. 6. 2016].

Ramovš, J. \& Ramovš, K., 2007. Pitje mladih: raziskava o pitju alkohola med mladimi v luči antropoloških spoznanj o omamah in zasvojenosti. Ljubljana: Inštitut Antona Trstenjaka za gerontologijo in medgeneracijsko sožitje.

Rassool, G.H., 2007. International perspectives: the educational experiences and previous orientation of undergraduate nursing students in alcohol and drug: the English context. Journal of Addictions Nursing, 18(1), pp. 47-52. http://dx.doi.org/10.1080/10884600600995499 
Snyder, L., 2006. Effects of alcohol advertising exposure on drinking among youth. Archives of Pediatrics and Adolescent Medicine, 160(1), pp. 18-24.

http://dx.doi.org/10.1001/archpedi.160.1.18

PMid:16389206

Stergar, M., 2011. Evropska raziskava o alkoholu in preostalih drogah med šolsko mladino 2011. Available at: http://www.cilizadelo.si/e files/content/ESPAD\%202011 Slovenija.pdf [11. 4. 2016].

Tremblay, P.F., Graham, K., Wells, S., Harris, R., Pulford, R., Roberts, S.E., 2010. When do first-year college students drink most during the academic year? An Internet-based study of daily and weekly drinking. Journal of American College Health, 58 (5), pp. 401-11.

http://dx.doi.org/10.1080/07448480903540465

PMid: 20304752

Varela, A. \& Pritchard, M.E., 2011. Peer influence: use of alcohol, tobacco, and prescription medications. Journal of American College Health, 59(8), pp. 751-756.

http://dx.doi.org/10.1080/07448481.2010.544346

PMid:21950257
Watson, H., Whyte, R., Schartau, E. \& Jamieson, E., 2006. Survey of student nurses and midwives: smoking and alcohol use. British Journal of Nursing, 15(22), pp. 1212-1216.

http://dx.doi.org/10.12968/bjon.2006.15.22.22557

PMid:17346018

World Medical Association, 2013. World Medical Association Declaration of Helsinki: ethical principles for medical research involving human subjects. Journal of the American Medical Association, 310(20), pp. 2191-2194. Available at:

http://www.wma.net/en/20activities/10ethics/10helsinki/ DoH-Oct2013-JAMA.pdf [1. 9. 2016].

Zalta, A., Kralj, A., Zurc, J., Lenarčič, B., Medarič, Z. \& Simčič, B., 2008. Mladi in alkohol v Sloveniji. Zaključno poročilo ciljnoraziskovalnega projekta. Koper: Univerza na Primorskem; Znanstveno-raziskovalno središče.

Cite as/Citirajte kot:

Pivač, S. \& Skela-Savič, B., 2016. Factors associated with greater potential for alcohol misuse among the students of the Gorenjska region. Obzornik zdravstvene nege, 50(4), pp. 280-295. http://dx.doi.org/10.14528/snr.2016.50.4.103 